\title{
Time Interval Between Staging FDG Positron Emission Tomography (PET) and Initiation of Stereotactic Lung Radiotherapy (SBRT) Impacts the Risk of Recurrence and Metastasis in Non-small Cell Lung Cancer (NSCLC)
}

B. Belderbos

Netherlands Cancer Institute

A. Hope

Princess Margaret Hospital and University of Toronto

L. L. Kestin

William Beaumont Hospital Follow this and additional works at: https://jdc.jefferson.edu/bodinejournal

- Gugkentherger ology Commons

University of Kuerzburn how access to this document benefits you

M. Werner-Wasik

Thomas Jefferson University and Hospitals

Recommended Citation

Belderbos, B.; Hope, A.; Kestin, L. L.; Guckenberger, M.; Werner-Wasik, M.; Sonke, J. J.; Bissonnette, J. P.;

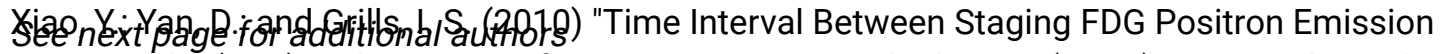

Tomography (PET) and Initiation of Stereotactic Lung Radiotherapy (SBRT) Impacts the Risk of

Recurrence and Metastasis in Non-small Cell Lung Cancer (NSCLC)," Bodine Journal: Vol. 3 : Iss. 1 , Article 23.

DOI: https://doi.org/10.29046/TBJ.003.1.022

Available at: https://jdc.jefferson.edu/bodinejournal/vol3/iss1/23

This Article is brought to you for free and open access by the Jefferson Digital Commons. The Jefferson Digital Commons is a service of Thomas Jefferson University's Center for Teaching and Learning (CTL). The Commons is a showcase for Jefferson books and journals, peer-reviewed scholarly publications, unique historical collections from the University archives, and teaching tools. The Jefferson Digital Commons allows researchers and interested readers anywhere in the world to learn about and keep up to date with Jefferson scholarship. This article has been accepted for inclusion in Bodine Journal by an authorized administrator of the Jefferson Digital Commons. For more information, please contact: JeffersonDigitalCommons@jefferson.edu. 
Time Interval Between Staging FDG Positron Emission Tomography (PET) and Initiation of Stereotactic Lung Radiotherapy (SBRT) Impacts the Risk of Recurrence and Metastasis in Non-small Cell Lung Cancer (NSCLC)

Authors

B. Belderbos, A. Hope, L. L. Kestin, M. Guckenberger, M. Werner-Wasik, J. J. Sonke, J. P. Bissonnette, Y. Xiao, D. Yan, and I. S. Grills 


\title{
Time Interval Between Staging FDG Positron Emission Tomography (PET) and Initiation of Stereotactic Lung Radiotherapy (SBRT) Impacts the Risk of Recurrence and Metastasis in Non-small Cell Lung Cancer (NSCLC)
}

\author{
Yan, D., ${ }^{3}$ Grills, I.S. ${ }^{3}$ \\ ${ }^{1}$ Netherlands Cancer Institute, Amsterdam, Netherlands \\ ${ }^{2}$ Princess Margaret Hospital and University of Toronto, Toronto, ON \\ ${ }^{3}$ William Beaumont Hospital, Royal Oak, MI \\ ${ }^{4}$ University of Wuerzburg, Wuerzburg, Germany \\ 5Department of Radiation Oncology, Thomas Jefferson University and Hospitals, Philadelphia, PA
}

Belderbos, B., ${ }^{1}$ Hope, A., ${ }^{2}$ Kestin, L.L., ${ }^{3}$ Guckenberger, M., ${ }^{4}$ Werner-Wasik, M., ${ }^{5}$ Sonke, J.J., ${ }^{1}$ Bissonnette, J.P., ${ }^{1}$ Xiao,Y., ${ }^{5}$

\section{Background}

To study influence of time interval from staging PET scanning to RT start time on recurrence and survival in patients with NSCLC undergoing lung SBRT.

\section{Methods}

Four-hundred eleven patients were treated with lung SBRT for T1-T2N0M0 NSCLC at 5 international institutions using online cone-beam CT (CBCT) image-guided radiotherapy (Elekta Oncology CBCT) from the period 1998 to 2009. Eight percent (8\%) of patients had a synchronous primary tumor and $62 \%$ of tumors were biopsyproven. All patients were staged with a diagnostic CT scan; $84 \%$ also had FDG-PET and 5\% had CT, PET and mediastinoscopy. Sixty-eight percent $(68 \%)$ had T1N0 tumors, $30 \%$ T2N0 and 1\% were locally recurrent after surgery. The median maximum tumor dimension was $2.4 \mathrm{~cm}$ (range $0.9-8.5 \mathrm{~cm}$ ). Patients were treated with a variety of prescription doses according to each institution's protocol. The most common fractionation schedules were: $18-20 \mathrm{~Gy}$ x 3; 12Gy x 4; 12Gy $\mathrm{x} 5$; and $12.5 \mathrm{~Gy}$ x 3 (median dose $54 \mathrm{~Gy}, 3$ fractions). Mean follow-up time $=1.3 \mathrm{y}$.

\section{Results}

Median time from PET to SBRT was 5.7 weeks (wks) (0-30.4 wks); median number of days elapsed during RT was $8 \mathrm{~d}$. Thirteen percent $(13 \%)$ of patients underwent PET $\leq 2$ wks of SBRT, while $76 \%$ underwent PET $\leq 8.5$ wks of SBRT. The median time from mediastinoscopy to SBRT was "x" wks (range). For all patients, $1 \mathrm{y}$ overall survival (OS) and cause specific survival (CSS) were $83 \%$ and $94 \%$, and at 2 y $64 \%$ and $91 \%$, respectively. Two years OS and CSS for patients who underwent PET staging were $62 \%$ and $87 \%$ compared to
$44 \%$ and $74 \%$ for those who did not ( $\mathrm{p}=0.03,0.04$, respectively). There were no differences in local recurrence (LR) or regional recurrence (RR) for patients undergoing staging PET vs. no PET ( $\mathrm{p}=\mathrm{NS}$ ); LR $7 \%$ vs $8 \%$, RR $9 \%$ vs $13 \%$. However, DM was substantially higher in those without staging PET vs. those with staging PET (37\% no PET vs. $22 \%$ PET, $\mathrm{p}=0.007$ ), as was the risk of death (Hazard ratio 1.53 for no PET, $\mathrm{p}=0.03$ Cox regression). Although the mere staging presence of PET did not impact the risk of RR, the time from staging PET to SBRT predicted both RR and DM, with a trend for predicting death on multivariate analysis $(\mathrm{p}=0.1)$. Patients undergoing PET $\leq 8.5 \mathrm{wks}$ of SBRT had RR of $10 \%$ vs. $24 \%$ for a time interval $>8.5$ wks from PET to SBRT start. A time interval $>8.5$ wks from PET to SBRT start doubled the risk of DM from $18 \%$ to $37 \%$ ( $\mathrm{p}=0.02$ ). No statistically significant differences existed in any recurrence or survival endpoints for patients undergoing vs. not mediastinoscopy.

\section{Conclusion}

The use of staging PET prior to SBRT for NSCLC improved OS and CSS and substantially reduced DM and death. A time interval $>8.5$ weeks between staging PET and initiation of SBRT increased the risk of RR and DM. The results of this analysis substantiate the importance of staging PET for NSCLC patients treated curatively with SBRT and emphasize the importance of timely staging for optimal outcomes. 